\title{
The revisionist historiography of Britain's decolonisation conflicts and political science theses of civilian victimisation in counterinsurgency
}

Article

Accepted Version

Scarinzi, F. (2019) The revisionist historiography of Britain's decolonisation conflicts and political science theses of civilian victimisation in counterinsurgency. Small Wars and Insurgencies, 30 (2). pp. 421-446. ISSN 0959-2318 doi: https://doi.org/10.1080/09592318.2019.1602245 Available at https://centaur.reading.ac.uk/82437/

It is advisable to refer to the publisher's version if you intend to cite from the work. See Guidance on citing.

To link to this article DOI: http://dx.doi.org/10.1080/09592318.2019.1602245

Publisher: Taylor \& Francis

All outputs in CentAUR are protected by Intellectual Property Rights law, including copyright law. Copyright and IPR is retained by the creators or other copyright holders. Terms and conditions for use of this material are defined in the End User Agreement. 


\section{CentAUR}

Central Archive at the University of Reading

Reading's research outputs online 
The Revisionist Historiography of Britain's Decolonisation Conflicts and Political Science Theses of Civilian Victimisation in Counterinsurgency.

Author: Dr. Fausto Scarinzi

Department of Politics and International Relations, University of Reading, Reading, UK.

fausto.scarinzi@gmail.com 
The Revisionist Historiography of Britain's Decolonisation Conflicts and Political Science Theses of Civilian Victimisation in Counterinsurgency.

\begin{abstract}
Recent historical research exposed the myth of self-restraint as the distinctive feature of British counterinsurgency during decolonisation. This article shows that the revisionist historiography of British counterinsurgency has important, but unnoticed, implications for political scientists. Specifically, historical scholarship challenges the predictions and causal mechanisms of the main social scientific theses of civilian victimisation in counterinsurgency. Using revisionist historians' works as a source of data, I test those theses against Britain's decolonisation conflicts. I find that they do not pass the test convincingly. I conclude that political scientists should be more willing to explore the theoretical implications of new historical evidence on counterinsurgency campaigns.
\end{abstract}

Key words: Historiography, British decolonisation, counterinsurgency, civilian victimisation, non-combatants; theory, test. 


\section{Introduction}

British counterinsurgency during decolonisation has long enjoyed the status of paradigm among scholars and practitioners. When compared to the brutal but unsuccessful campaigns of the United States in Vietnam and the Soviet Union in Afghanistan, Britain's performance in expeditionary counterinsurgency looked different. The conventional wisdom - reflecting the influence of Robert Thompson's analysis of the British campaign in Malaya ${ }^{1}$ - maintained that Britain's relative success in counterinsurgency during decolonisation resulted from 'hearts and minds' measures and limited violence against non-combatants, which enabled Britain to win over the local population, undermine insurgents' popular base, and destroy the enemy while sparing as many innocent lives as possible. $^{2}$

In the early 1990s, historians began to question the dominant narrative of British counterinsurgency. Showing new evidence from primary sources, revisionist historians highlighted that, in fact, violent coercion against civilians was at the core of Britain's counterinsurgency doctrine and practice during decolonisation. ${ }^{3}$ Revisionist historians did not claim that Britain entirely lacked discrimination in the use of force; they argued that 'British counterinsurgency was conducted in a more complex, and also often in a more coercive way than long-prevailing analyses based on the alleged centrality of minimum force would suggest'. Indeed, coercion against civilians in British counterinsurgency ranged from relatively mild measures like curfews, cordon-and-search operations, mass screening, collective fines, house evictions, and mass arrests to brutal measures like mass deportation to concentration camps or new villages, scorched earth and food denial, torture, the creation of free-fire zones, indiscriminate shootings, and summary executions. ${ }^{5}$

Dismissing as artificial the idea that persuasion and coercion would be mutually exclusive in counterinsurgency, revisionist historians showed that Britain used both persuasive and coercive measures and the balance between the former and the latter changed over time and space. ${ }^{6}$ Indeed, Britain did not use the same level of brutality in each campaign. In some campaigns - like the Kenya Emergency (1952-1960) - the British targeted the local population indiscriminately, while in other conflicts - like the campaigns in Palestine (1945-1947) and Cyprus (19551959) - Britain strove to avoid harm on non-combatants. The balance between 
coercion and persuasion did not vary only across different campaigns, but also during the same campaign. The Malayan Emergency (1948-1960), for example, went through different phases and displayed a different combination of coercion and persuasion in each phase. ${ }^{7}$ In sum, the revisionist works on British counterinsurgency found a higher degree of variation in the use of indiscriminate violence than the conventional wisdom had acknowledged.

This article highlights the importance of the revisionist historiography of British counterinsurgency during decolonisation for political scientists. More specifically, I show that the historical scholarship on British counterinsurgency challenges the main social scientific explanations for indiscriminate violence in anti-guerrilla warfare. Relying on the research of revisionist historians as a source of evidence, I will test current social scientific theses of civilian victimisation against the main cases of British counterinsurgency during decolonisation. ${ }^{8}$ In particular, I will look at the British campaigns in Palestine (1945-1947), Malaya (1948-1960), Kenya (1952-1960) and Cyprus (1955-1959). ${ }^{9}$

The critical use of historical scholarship as a source of evidence to elucidate and test the causal logic and the explanatory power of a theory is widely accepted in political science research. ${ }^{10}$ However, that practice entails that political scientists should be ready to explore how new historical evidence and interpretations may affect the accuracy of their theories. Yet, while social scientific theories often build upon historical evidence and interpretations, political scientists do not always reassess the explanatory power and the causal logic of their theses in response to the evolution of historiographical debates; in this way, political scientists may fail to rethink, refine, and update their arguments, once anomalous historical evidence has emerged. ${ }^{11}$

The theoretical scholarship on the causes of civilian victimisation in counterinsurgency mirrors this tendency. The British experience in counterinsurgency is prominent as a source of evidence in the social scientific literature on the way states fight against insurgents. Specifically, political scientists tend to accept the conventional wisdom on British counterinsurgency and often point to Britain's alleged self-restraint as evidence confirming their arguments. ${ }^{12}$ Surprisingly, while historians have revised the argument that minimum force was the distinctive feature of British counterinsurgency during decolonisation, political scientists have not asked what that means for their 
theses. In sum, it looks as though the latest round of historical research on British violence against civilians has gone unnoticed.

This paper shows that the revisionist scholarship on British counterinsurgency has serious implications for political scientists. Specifically, that scholarship often contradicts the predictions and the causal mechanisms of social scientific theses of civilian victimisation in counterinsurgency, therefore the revisionist historiography of Britain's decolonisation conflicts invites political scientists to consider how contrary evidence bears on the validity of their theses and explore whether - and to what extent - the causal mechanisms and logic of their arguments should be amended.

The remainder of this article will proceed as follows. As a first step, I will set out the main social scientific theses of civilian victimisation in counterinsurgency, their predictions, and the corresponding causal logic. As a second step, I will test those theses against the evidence emerging from revisionist historians' research on Britain's decolonisation conflicts. Relying on the main strengths of the case study method - the exploration and close observation of causal mechanisms ${ }^{13}$ - I will follow the congruence procedure using observations within cases. I will begin by observing the values on the candidate causal factors of the above-mentioned theses in the cases of interest; based on that, I will specify the predictions of those theses about Britain's conduct towards civilians; finally, I will check if the case outcome confirms those predictions and if that outcome actually resulted from the posited causal mechanism. ${ }^{14}$ I will show that the latest historical research on the conflicts of British decolonisation indicates that events were rarely unfolding according to the predictions and causal logic of political science theses of indiscriminate violence. As a third step, I will present my conclusions.

\section{Political Science Theses of Civilian Victimisation in Counterinsurgency}

A glance at the history of international politics in the last two centuries would be enough to notice that states have often been involved in protracted campaigns against insurgencies abroad. ${ }^{15}$ States have fought irregular opponents beyond their national borders to preserve their colonies and territorial possessions, protect friendly governments or allied regimes from local rebellions, or remove perceived terrorist threats, as the recent campaigns in Afghanistan and Iraq would suggest. 
The states involved in expeditionary counterinsurgency, however, have faced their enemies with different military strategies. In some cases, the counterinsurgent tried to defeat the opponent with a relatively high level of indiscriminate violence and coercion, while doing the opposite in other cases; moreover, the level of violence against non-combatants also varied within the same cases. Hence a question: under which conditions do states victimise civilians as a strategy to defeat guerrilla insurgencies abroad ${ }^{16}$

The political science literature on civilian targeting as a counterinsurgency strategy tends to focus on the impact of indiscriminate violence on war outcome, thus analysing civilian victimisation as a causal factor that may explain why states win or lose against insurgents. ${ }^{17}$ Social scientific studies on the effectiveness of indiscriminate violence include self-contained causal arguments that clearly explain why states may choose a civilian targeting strategy in antiguerrilla warfare. In fact, those studies often explore the reasons why states may choose to target civilians, even if state leaders may be aware that indiscriminate violence may be ineffective or self-defeating, and vice versa. ${ }^{18}$ In addition to that, a fast-growing body of political science scholarship explicitly addressed civilian targeting in counterinsurgency as a phenomenon to be explained regardless of its effect on war outcome. ${ }^{19}$ Looking at the political science literature, therefore, one can spot rival theses about the causes of civilian victimisation in counterinsurgency. Those theses point to competing causal factors like regime type, military organisational interests, military culture, force structure and intelligence collection capabilities, the perceived image of the opponent, and the military power of the insurgent that may exacerbate the counterinsurgent's desperation to win.

\section{Regime Type and Civilian Victimisation}

Scholars disagree about the impact of regime type on the use of indiscriminate violence in counter-guerrilla warfare. Some authors contend that liberal democracies would be unlikely to victimise civilians, especially in non-existential conflicts like counterinsurgency campaigns abroad. Gil Merom, in particular, argues that when democratic leaders try to use civilian targeting strategies, small groups of educated middle-class citizens would exploit democratic norms allowing public debate to repudiate indiscriminate violence as morally 
unacceptable and turn the domestic public opinion against the government; faced with massive moral indignation and the prospect of political defeat, elected leaders would eventually give in to public pressure and fall back on self-restraint strategies. $^{20}$

Other scholars, instead, warn that elected leaders would be anxious to keep down the human and financial costs of non-existential conflicts on their own side to prevent a loss of consent and achieve tenure in office. ${ }^{21}$ Military strategies relying on overwhelming firepower and indiscriminate violence would fit the purpose. Indeed, those strategies would replace manpower with capital (tanks, artillery, aircraft etc.), which would reduce soldiers' exposure to the insurgent's firepower; capital-intensive strategies would also charge the financial costs of counterinsurgency campaigns on a relatively insignificant number of wealthy voters. $^{22}$ Democracies, in sum, would target civilians in counterinsurgency because indiscriminate violence would protect the life and wealth of most citizens on their side, while saving leaders' chances to win the next elections.

\section{Military Organisational Factors and Civilian Victimisation}

Another group of arguments suggests that civilian targeting would depend on the characteristics of the military organisation fighting against the insurgent and civilmilitary relations, rather than regime type.

Some scholars point to military organisational interests as a cause of civilian targeting. ${ }^{23}$ They build on the bureaucratic politics assumption that all organisations pursue independence from external oversight, control over their own affairs, and more financial resources. ${ }^{24}$ As bureaucratic entities, military organisations would prefer strategies conceived to destroy the enemy and its popular base through preponderant technology and firepower; indeed, that type of strategy, while harming non-combatants, would make for higher military budgets and tighter control over the conduct of military operations. ${ }^{25}$ Consequently, states would be more likely to victimise non-combatants when political leaders are unwilling or unable to restrain military organisations' institutional preference for the indiscriminate use of force. ${ }^{26}$

Still other scholars argue that the preferences of military organisations about how to fight would derive from military culture that would set standards of appropriate behaviour. Military culture would express military organisations' 
beliefs about their own identity, essence and purpose, which would cause military organisations to look at some types of force employment as appropriate and dismiss others as incompatible with their own identity, regardless of the perceived identity of the enemy. ${ }^{27}$ According to this argument, civilian victimisation would be more likely when military culture stresses the exemplary punishment of the enemy as the task defining the identity and mission of a military organisation and political leaders do not intervene to restrain the army. ${ }^{28}$

Another argument stresses that the way military organisations deal with noncombatants depends on force structure intended as 'the specific mixture of materiel and personnel that compromises a military's war-making capabilities' ${ }^{29}$ This argument predicts that military organisations would be likely to use indiscriminate violence in counterinsurgency when their force structure is based on mechanisation. Mechanised militaries would have limited manpower compared to machines, which would undermine their ability to interact with the local population, win civilians' trust, and obtain intelligence about insurgents. ${ }^{30}$ Lacking information about the enemy, mechanised forces could not distinguish combatants from non-combatants and would use violence indiscriminately; when force structure is based on manpower, instead, the counterinsurgent would be more likely to obtain intelligence about the enemy and use violence only against the insurgent. ${ }^{31}$

\section{The Image of the Enemy and Civilian Victimisation}

Another argument rooted in social identity theory holds that the perceived identity of the enemy would be the main cause of civilian victimisation in warfare. According to social identity theory, human beings tend to place each other into different social groups and show greater suspicion and aggressiveness against members of out-groups. ${ }^{32}$ This tendency may be more prominent during an armed conflict and it may propel indiscriminate violence. The belief that one is dealing with an out-group of 'evil', 'barbaric', or even 'sub-human' individuals would broaden the scope of what is morally acceptable in warfare so that indiscriminate violence would be seen as fully legitimate, if not desirable. ${ }^{33}$ According to Hugo Slim, the demonisation of the enemy would mirror a radical anti-civilian ideology according to which there is no such a thing as a noncombatant in the enemy population. ${ }^{34}$ However, the vilification of non- 
combatants can also derive from the ambiguity of the civilian identity in warfare. Even if they may never carry guns, civilians may often participate - more or less willingly - in the conflict between the insurgent and the counterinsurgent by providing the former with economic support, food, shelter, and information. ${ }^{35}$ Under those conditions, the counterinsurgent may perceive civilians as accomplices of the enemy and may regard the populace as a military target.

In conclusion, if the counterinsurgent vilifies the insurgent and its popular base, civilian victimisation will occur; otherwise, the counterinsurgent will be selfrestrained.

\section{Desperation to Win and Civilian Victimisation}

Rejecting all the explanations set out above, the latest political science scholarship maintains that indiscriminate violence in counterinsurgency would be a strategy of later resort deriving from desperation to win against powerful and popular insurgencies.

This thesis assumes that states want quick victories with low combat losses, which is why state leaders would refrain from civilian targeting in the beginning of a campaign. ${ }^{36}$ Indeed, indiscriminate violence may exacerbate resistance from victim groups and cause civilians to side with insurgents, which would increase the duration and costs of the conflict. ${ }^{37}$ Yet, when hostilities last longer than expected, population control has been lost, combat casualties mount, and victory seems in question, state leaders would become desperate to defeat the insurgent and the risks of a civilian targeting strategy would appear less significant than its potential advantages: specifically, civilian victimisation would crush the insurgent's popular base and prevent the implementation of a guerrilla strategy. ${ }^{38}$

Therefore, the desperation thesis would predict that civilian targeting will be very limited, if not absent, in the early stage of counterinsurgency campaigns when the counterinsurgent is still confident in a quick victory with limited losses. The counterinsurgent, however, will escalate indiscriminate violence as the conflict goes on, but only if insurgents have gained population control and have become militarily powerful; otherwise, the counterinsurgent will be selfrestrained and will not target civilians. ${ }^{39}$ 


\section{Testing Theses of Civilian Victimisation on Britain's Decolonisation Conflicts.}

While political scientists have provided evidence showing the plausibility of their arguments, current theses of civilian victimisation need more tests. Indeed, some of the most important studies on civilian targeting addressed interstate conventional conflicts and examined counterinsurgency to a very limited extent, even if their authors do insist that their arguments would apply to anti-guerrilla warfare too. ${ }^{40}$ Other works did focus on counterinsurgency but their authors simply considered extreme forms of civilian targeting, observing only those campaigns in which the counterinsurgent intentionally perpetrated mass murder or genocide. ${ }^{41}$ Finally, other works that looked at expeditionary counterinsurgency studied only one or two campaigns, which means that the causal logic of their arguments about indiscriminate violence has not been tested extensively. ${ }^{42}$

In this article, I test the above-mentioned arguments and their causal logic against the main conflicts of British decolonisation after 1945. In particular, I will look at historians' research on Britain's counterinsurgency in Palestine (19451947), Malaya (1948-1960), Kenya (1952-1960), and Cyprus (1955-1959). In pursuit of my research aim, I will rely on the congruence procedure and I will use the revisionist historical research on British counterinsurgency during decolonisation as a source of data, as explained above. I will check whether the specific outcome on the use of indiscriminate violence is correctly predicted by the theses being tested and whether that outcome actually resulted from the posited causal mechanism. I find that historical evidence about Britain's conduct towards non-combatants often runs counter to the predictions of political science theses of civilian victimisation and the respective causal processes.

\section{Political Science Theses of Civilian Victimisation against Historical Evidence}

Despite the importance of the revisionist research on Britain's decolonisation conflicts, political scientists have paid scant attention to it. Indeed, looking at social scientific studies on civilian victimisation, one can find that Britain's counterinsurgency campaigns during decolonisation are still mentioned as instances of self-restraint reflecting a 'benevolent approach to counterinsurgency'. ${ }^{43}$ The recent historiography of British decolonisation 
conflicts does not confirm such a positive assessment and challenges the explanatory power of political science theses of civilian victimisation in counterinsurgency.

Britain's conduct to civilians would not confirm the predictions of the regime type argument and its causal processes in important cases. The democratic restraint version of the regime type argument is contradicted by Britain's relentless use of indiscriminate brutality in Kenya. The Kenya Emergency (19521960) was one of the fiercest decolonisation campaigns fought by Britain. During the campaign in Kenya over a million civilians were deported to new villages where they experienced forced labour, beatings and torture, sexual abuses, food deprivation, malnutrition, starvation, and disease; ${ }^{44}$ thousands suffered torture during screening operations; ${ }^{45}$ over 430 cases of indiscriminate shootings were recorded in the first six months of the conflict. ${ }^{46}$ According to a conservative estimate, at least 12,000 adult non-combatants - mostly women - and 26,000 children under the age of ten died during the Kenya Emergency because of violence or the disruptions caused by Britain's repression. ${ }^{47}$

Considering that Britain was one of the most democratic states in the world during decolonisation, the restraining effects of democracy should have been easily observable. Instead, not only did Britain target civilians in Kenya, but British leaders could also overcome any concern about the risk of an outraged reaction from the domestic society. While critical voices invariably accompanied the indiscriminate use of force in the colonies, the British public opinion never turned against the government on the ill-treatment of civilians in those campaigns. $^{48}$

The latest historical studies on the Kenya Emergency, for example, point out that the Labour opposition in the House of Commons, the British press, and the other media did very little to expose the systematic ill-treatment of noncombatants and the public opinion was mildly interested in the fate of civilians in Kenya until 1955 when military operations had almost ceased. ${ }^{49}$ After the mass deportation of the Kikuyu tribe, the dreadful conditions of living of potential Mau Mau sympathisers in concentration camps generated more outcry in Britain than ever before, but the government's conduct did not change: the British Cabinet successfully resisted all objections and carried on with its policies. ${ }^{50}$

The democratic restraint thesis would apparently perform better in the case of 
the Malayan Emergency as Britain exercised much more discrimination in the use of violence compared to Kenya. Overall, the Malayan Emergency (1948-1960) was far less brutal than the British campaign in Kenya. Yet, if we think of the British campaign in Malaya as a protracted conflict with different phases - as revisionist historians suggest ${ }^{51}$ - rather than a monolithic whole, the democratic restraint thesis would not pass the test of the Malayan Emergency convincingly. Recent studies on the Malayan Emergency showed that in the early stage of the conflict - from June 1948 to December 1949 - Britain adopted a military strategy based on counter-terror, property destruction, forced population movement, and the indiscriminate use of firepower. ${ }^{52}$ The democratic restraint thesis could not explain why democratic Britain adopted a counter-terror strategy in the first phase of the campaign and deliberately targeted civilians with the destruction of villages, mass deportations, and indiscriminate shootings until the end of $1949 .{ }^{53}$ Perhaps more importantly, if we look at the following phases of the conflict - the 'clear and hold' phase of 1950-1952 with the transfer of almost 400,000 Chinese squatters to new villages and the 'optimisation' phase of 1952-1960 marked by hearts and minds measures ${ }^{54}$ - the causal logic of the democratic restraint thesis is not confirmed. Indeed, Britain's conduct towards civilians was shaped by the strategic situation on the field rather than a concern with British public opinion's moral outrage against civilian targeting. In particular, Britain's self-restraint after 1952 was a direct consequence of the successful resettlement of Chinese civilians - sometimes coerced, sometimes not - that separated insurgents from their popular base and enabled Britain to discriminate combatants from noncombatants more effectively. ${ }^{55}$

The case of Malaya would not support the democratic propellant version of the regime type argument that would predict that British leaders should have adopted a civilian targeting strategy to shift the costs of the conflict to the opponent and save their domestic popularity. In fact, Britain was relatively self-restrained and British leaders had no concerns that they could lose the next elections because of the costs of the Malayan Emergency. ${ }^{56}$

The democratic propellant thesis, however, would correctly predict the use of civilian victimisation in Kenya, as Britain did target non-combatants in that campaign. Yet, even in that case the revisionist historical scholarship on Britain's decolonisation conflicts would challenge the causal logic of the democratic 
propellant thesis according to which civilian targeting would derive from elected leaders' effort to achieve tenure in office. In fact, British leaders never showed any concern that the campaign in Kenya could determine the fate of the government in Britain. Indeed, the British Cabinet looked at the Kenya Emergency as a minor conflict against weak opponents in the periphery of the Empire. ${ }^{57}$ Furthermore, as we have just seen, the British parliament and public opinion rarely took an interest in the Kenya Emergency and, when they did so, the government successfully defended its policies. As a result, the use of indiscriminate violence in those campaigns seems to have little to do with British leaders' fear to lose the next elections. Overall, the performance of the regime type argument is dubious at best: both the democratic restraint and the democratic propellant theses fail tests that should have passed easily.

The theses looking at military institutional and cultural factors as the mainspring of civilian targeting would equally find favourable conditions to explain Britain's brutality against civilians during decolonisation, as confirmed by revisionist historians themselves. For example, revisionist historians stress that in the 1940s and 1950s the principle of non-combatant immunity was not yet embedded in the British Army's military culture as a standard of appropriate behavior in colonial warfare and Britain's counterinsurgency doctrine was still based on civilian targeting and exemplary force ${ }^{58}$ Historians also point out that Britain struggled with a shortage of manpower affecting intelligence collection capabilities in every decolonisation conflicts. ${ }^{59}$ Finally, civil authorities and military commanders were reluctant to restrain the security forces, as they believed that tight constraints on the use of violence would undermine troops' morale and combat effectiveness. ${ }^{60}$ Under these conditions, military organisational factors would be expected to fuel British brutality. Interestingly, historians argue that military culture, lack of information about the enemy, and the permissive attitude of civilian and military leaders would help explain some forms of British violence like torture during screening operations and indiscriminate shootings in Kenya, or the use of counter-terror in the initial phase of the Malayan Emergency. ${ }^{61}$

Military organisational factors, however, have more causal importance when political leaders and civil agencies are not directly involved in the repression of insurgents and the army is the only organisation in charge to deal with the enemy's popular base; otherwise, the impact of political leaders and agencies 
other than the army should be assessed. The theoretical scholarship on military organisational factors and civilian victimisation in counterinsurgency tends to ignore the role of political leaders and civil agencies as perpetrators of violence against non-combatants. Indeed, that scholarship sticks to a dichotomy between political leaders' alleged preference for 'the use of limited force to reassure allies, persuade insurgents to negotiate, or deny insurgents a country's population centres' versus the institutional preference of military organisations for overwhelming force to destroy the insurgent's sanctuaries in the civilian population. ${ }^{62}$ As a result, civilian intervention in the planning and conduct of counterinsurgency campaigns is only seen as a source of self-restraint, while the use of indiscriminate violence is mostly attributed to military organisations and their commanders. Yet, political leaders and civil agencies can propel civilian targeting to such an extent that military organisational factors may not be sufficient to explain the use of indiscriminate violence in counterinsurgency.

Interestingly, revisionist historians show that British political leaders, the civil administration and the police - while acknowledging the operational autonomy of military commanders - did not yield their authority to the British Army and played an active role in the punishment of civilians. ${ }^{63}$ Consequently, the organisational interests, military culture, and force structure of the British Army would not be enough to explain a significant part of British violence against noncombatants in important cases.

British counterinsurgency in Kenya supports this point. Recent historical studies on the Kenya Emergency reveal that political leaders were responsible for some of the most brutal policies against non-combatants, while the police and loyalist auxiliary units - like the Kenya Police Reserve (KPR) and the Home Guard (HG) - were routinely involved in the victimisation of civilians. ${ }^{64}$

For example, it was the Governor of Kenya himself - Sir Evelyn Baring - that adopted a policy of mass evictions against Kikuyu people living on settlers' land since the beginning of the campaign, displacing at least 70,000 civilians - mostly women and children - between November 1952 and April $1953 .{ }^{65}$ Once evicted, civilians were deported to overcrowded African Reserves where they would be left homeless and hungry. Even if intelligence reports warned that mass evictions would cause famine and death, the Governor insisted to carry on with that policy because it would appease white settlers and prevent the rebellion from spreading 
to other Provinces. ${ }^{66}$

Secondly, extrajudicial executions were frequent and did not involve only the British Army. In fact, the KPR and the HG, which were under the civil administration in the colony, ${ }^{67}$ perpetrated the fiercest reprisals against noncombatants. In March 1953, after some Mau Mau gangs killed 120 loyalist civilians in Lari, the HG and the KPR retaliated by shooting at least twice as many people indiscriminately. ${ }^{68}$ In June 1953, the HG killed 400 non-combatants as a reprisal after the insurgent assassinated the son of a loyalist leader. ${ }^{69}$ Importantly, while military commanders tried to restrain the Army, the KPR and the HG escaped military discipline and their conduct towards non-combatants did not change significantly. ${ }^{70}$

Finally, the civil administration, the police and the HG also stood out for their systematic brutality against the civilians deported to new villages after January 1954; the British Army, instead, had little to do with the conditions of living in detention camps. Indeed, while the British Army carried out mass deportations, only the Governor and the civil administration were in charge to manage approximately 840 new villages where the police and the HG watched over inmates and imposed the infamous rehabilitation programmes through torture. ${ }^{71}$ Infant mortality in punitive villages was high because of systematic food deprivation, intentional neglect of sanitation, and denial of medical care. ${ }^{72}$ Given the insignificant role of the British Army in the management of new villages, military organisational factors cannot have had a decisive causal effect on the fate of inmates from 1954 onwards. In sum, explanations based uniquely on those factors would miss a very important part of British violence in Kenya. ${ }^{73}$

Political science theses based on military organisational factors would meet with serious difficulties in other cases too. For example, the force structure argument could not easily explain Britain's conduct towards civilians in the counterinsurgency campaigns in Palestine and Cyprus.

That might seem surprising. Indeed, those campaigns would display a correlation between Britain's limited use of military machines and self-restraint towards civilians. Yet, a deeper look into those cases would disclose serious flaws in the causal mechanism of the force structure argument. The causal mechanism of the force structure thesis is based on two statements: a) preference for manpower over machines is likely to generate popular support for the 
counterinsurgent and successful collection of information about the enemy, while preference for machines will generate the opposite effect; b) successful collection of intelligence about the enemy is likely to result in selective violence, while failure to get information about the opponent would lead to indiscriminate violence.

The cases of Palestine and Cyprus contradict both statements: Britain's preference for manpower was followed by the persistent hostility of the local population and very limited intelligence gains; failure to obtain popular support and information about the enemy was still followed by British self-restraint towards civilians rather than indiscriminate violence.

In both conflicts, Britain mostly relied on light infantry and police units. ${ }^{74}$ The preponderant use of manpower should have resulted in successful collection of information from civilians, but in fact the British would struggle to make intelligence gains against resilient guerrilla insurgencies that could count on the support of the Jewish settlers of Palestine and the Greek Cypriot population respectively. ${ }^{75}$ The local population was a crucial source of shelter, information, and resources for insurgents and prevented Britain's victory in both campaigns. Indeed, civilians' stubborn refusal to cooperate with Britain left the security forces without valuable information, thus affecting the counterinsurgent's ability to locate and destroy the insurgent. ${ }^{76}$ While Britain struggled to obtain information about the enemy, the insurgent successfully infiltrated the security forces - especially the police - and eliminated members of the Special Branch as well as Britain's informers. ${ }^{77}$ In Cyprus the insurgent used spies, informers, and selective violence so effectively that police officers tendered mass resignations out of fear to be killed. ${ }^{78}$ That would be inconsistent with the causal chain posited by the force structure argument, according to which the predominance of manpower over machines should enable the counterinsurgent to gather intelligence successfully.

Under those conditions of serious lack of information - surprisingly following from Britain's preference for manpower - the force structure argument would predict an escalation of indiscriminate violence by Britain. That, however, did not happen. Despite its failure to win over the local population and obtain information about the insurgency, the British security forces never used indiscriminate executions, torture, scorched earth tactics, food denial, and mass 
deportation in Palestine and Cyprus. In order to break civilians' resistance, the security forces resorted to bloodless methods like cordon-and-search operations, mass screening, mass arrests, collective fines, and property destruction. ${ }^{79}$ These measures did not change the behaviour of the populace and bombing attacks, ambushes, and sabotage operations could not be stopped; yet, the British never responded by targeting civilians with brute force. During the campaign in Cyprus, detainees frequently asserted that the security forces tortured prisoners, but recent historical studies show that most complaints - not all - were propaganda fabrications. ${ }^{80}$

The cases of Britain's counterinsurgency campaigns in Palestine and Cyprus would also challenge the vilification argument. Indeed, as Britain realised that civilians would stand firm on their support for the insurgency, the Jewish and Greek Cypriot communities were demonised as willing accomplices of terrorism and the security forces would consider insurgents' violence as a mere reflection of the abhorrent moral standards of the local population. In Palestine the association of the Jewish community with the insurgent was almost immediate and complete; as a result, the entire Jewish population was seen as 'unscrupulous', 'utterly immoral' and stubbornly committed to terrorism. ${ }^{81}$

In Cyprus, the initial belief of the colonial authorities that Greek civilians cooperated with EOKA out of fear was replaced by the perception that the Greek Cypriot community was a sadistic out-group willingly supporting terrorism. ${ }^{82}$ The assassination of British soldiers and civilians would be followed by news about Greek Cypriot ordinary people rejoicing on the murder scene, which was regarded as evidence of the 'moral delinquency' of the Greek community. ${ }^{83}$ The vilification of the Greek Cypriot community did not spare the Orthodox Church that was seen as 'the cover organisation of the whole terrorist conspiracy' ${ }^{84}$ According to the colonial authorities, the Church used its 'malignant power' to indoctrinate Cypriot youths with Greek nationalism and turn them into killers. ${ }^{85}$ Under these circumstances, the vilification argument would predict an escalation of civilian targeting in Palestine and Cyprus that, instead, never took place.

Britain's self-restraint in Palestine and Cyprus could be explained by pointing to the limited military power of the insurgent. That would confirm the desperation thesis according to which, if the insurgent poses only a minor military threat, the counterinsurgent will preserve its confidence in victory and refrain from targeting 
civilians. Yet, the desperation thesis would fail in other cases presenting favourable conditions, like the Kenya Emergency.

The desperation thesis would predict self-restraint in Kenya, especially in the opening phase of the campaign that was marked by moderate optimism about the outcome of the conflict on the British side. Indeed, Mau Mau insurgents posed a minor military threat as they lacked modern guns and used spears, axes, and knives in most of their attacks. Unsurprisingly, they killed only 200 servicemen and no more than 1,800 civilians in eight years. ${ }^{86}$ Faced with an enemy that could hardly shoot to kill, the British maintained their confidence in victory.

Historians suggest that Britain's initial optimism also depended on limited information about the enemy, which induced military commanders to underestimate the number of Mau Mau fighters. In his first assessment of the situation on the field as a Chief of Staff Officer in March 1953, General William N. Hinde claimed that there were just 13 Mau Mau gangs and a hundred hardcore fighters with no more than 55 guns. ${ }^{87}$ Few months later, the British authorities were still cautiously optimistic. In a telegram to the Colonial Secretary in May 1953 the Governor of Kenya wrote: 'the situation is better and the machine to deal with the rebellion greatly improved'; the Governor was relieved that there had been 'no significant spreading of Mau Mau rebellion to other tribes' and that 'Kikuyu are now coming into the open in increasing numbers in support of the Government'; Baring concluded that a swift victory was possible: 'I remain convinced that if we can now press home our advantage we might finish them [Mau Mau] off quickly' ${ }^{88}$

The problem with the desperation thesis is that Britain resorted to scorched earth, food denial, torture, free-fire zones and indiscriminate shootings in the first six months of the campaign against Mau Mau when the candidate causal factor of this thesis - desperation to win against a powerful and popular insurgency - was not present. ${ }^{89}$ This is a relevant flaw: considering insurgents' extreme military weakness, the low number of combat losses suffered by the security forces, and Britain's confidence in victory, the prediction that the counterinsurgent will be self-restrained in the early phase of a campaign when confronted with a minor military threat should have been easily confirmed. Britain, instead, used civilian victimisation as a strategy of early resort, even if it was not desperate to win yet.

Apparently, the desperation thesis would explain Britain's self-restraint in the 
case of the Malayan Emergency. Alexander Downes, for example, considers the Malayan Emergency as a successful test for the desperation thesis: he claims that Britain refrained from civilian targeting because the insurgent was neither powerful nor popular..$^{90}$ Downes, however, did not study the case of the Malayan Emergency in depth and looked at the conflict as a monolithic unit of analysis. In this way, Downes missed relevant variations in the strategy of Britain during the campaign and failed to notice that the Malayan Emergency, in fact, challenges the desperation thesis.

Revisionist historians suggested that the Malayan Emergency can be disaggregated into different phases and highlighted that Britain used a different degree of coercion in each phase. ${ }^{91}$ The strategy of Britain in the early stage of the campaign in Malaya would call into question the explanatory power and the causal logic of the desperation thesis. Specifically, recent historical research on the Malayan Emergency shows that Britain targeted civilians in the first phase of the conflict. From July 1948 to December 1949, Britain used a counter-terror strategy based on indiscriminate shootings, scorched earth tactics including the burning of houses and villages and the coercive deportation of over 18,000 noncombatants. ${ }^{92}$ The timing of British counter-terror in Malaya is inconsistent with the prediction that civilian targeting would occur as a measure of later resort.

More importantly, the reason behind the use of counter-terror does not confirm the causal logic of the desperation thesis that excludes that states may see indiscriminate violence as a convenient option to achieve a rapid victory against insurgents. Indeed, according to the desperation thesis, the counterinsurgent would prefer to avoid indiscriminate violence in the beginning of a conflict because it may increase civilians' support for the insurgent and hinder a quick victory.

Recent historical studies, instead, indicate that Britain chose a counter-terror strategy in the opening phase of the Malayan Emergency because it was supposed to lead to a rapid victory against an enemy that had not built a large popular base yet. Both military commanders and the Cabinet insisted on the need to intimidate the Chinese population of Malaya in order to increase support for the colonial government and defeat the insurgency quickly as long as it was still far from becoming powerful and popular. As the Colonial Secretary, Arthur Creech Jones, put it in July 1948: 'we want to strike hard from the start to make sure we are not 
faced with one of those lingering guerrilla campaigns'. ${ }^{93}$ Importantly, Britain's early resort to indiscriminate violence occurred while the British believed that the security forces were having the upper hand in the conflict. Indeed, in the first few months of the campaign, the security forces took few casualties and intelligence reports indicated that counter-terror was undermining popular support for the insurgent. ${ }^{94}$ Clearly, counter-terror in Malaya was not a strategy of later resort deriving from frustration about casualties and war outcome on the British side.

\section{Conclusions}

As attempts to explain patterns of behaviour, theories provide 'a common, more general and coherent explanation for a variety of specified cases' ${ }^{95}$ A theory 'indicates that some factors are more important than others and specifies the relations among them'; in this way, a theory 'connects otherwise disparate facts' and 'shows how changes in some of the phenomena necessarily entail changes in others ${ }^{9}{ }^{96}$ A theory, in sum, is a simplified picture of reality that explains - and possibly predicts - why and how some causal factors lead to a specific outcome under certain circumstances.

This article relied on the case study method and the congruence procedure to test political science theses of civilian victimisation in counterinsurgency against historical evidence about the campaigns of Britain in Palestine, Malaya, Kenya, and Cyprus. Using revisionist historians' studies on those campaigns as a source of data, I found that evidence often ran counter to the predictions and the causal logic of social scientific theses of indiscriminate violence in counterinsurgency.

One may observe that the study of four cases would not refute those theses decisively. Indeed, like any other social scientific theory, current theses of civilian victimisation cannot be expected to account for the use of indiscriminate violence in every campaign; consequently, some anomalous cases may not be enough to disprove social scientific arguments on indiscriminate violence.

That is true, but this article does not claim that revisionist historians' research on British counterinsurgency has falsified political science theses of civilian victimisation conclusively. This article, instead, argues that there are very clear indications that the explanatory power and the posited causal logic of those theses are weaker than it may appear. Indeed, political science theses of indiscriminate violence often perform poorly in cases that should have been explained easily. As 
we have seen, Britain was one of the most democratic states in the world during the decolonisation era, it routinely vilified its irregular opponents, and it invariably faced insurgent groups that had very limited military power. Under those conditions, the predictions and the causal mechanisms of the theses that point to the primacy of regime type, the vilification of the enemy, and the military threat posed by the insurgent should have been easily confirmed; in spite of that, historical evidence often contradicted those theses. Revisionist historians' studies on British counterinsurgency also suggest that the arguments explaining civilian targeting as a function of military organisational factors may actually miss the prominent causal role of political leaders and civil agencies as perpetrators of indiscriminate violence; therefore, those theses could not explain the level of brutality committed by non-military actors. Finally, revisionist historians brought up evidence that was inconsistent with the causal mechanisms of the theses pointing to military organisational factors, especially force structure.

The test carried out in this article leads to the conclusion that political scientists should be more willing to reassess their arguments and ascertain how anomalous evidence emerging from historical research affects the veracity of their explanations. Unfortunately, political scientists have been slow to react. That is perplexing because social scientific theses of civilian victimisation often mention Britain's decolonisation conflicts as a source of supporting evidence. More attention to the progress of the historiography of Britain's counterinsurgency campaigns, therefore, would be necessary because it would enable political scientists to update the empirical foundation of their theses and refine the causal logic of their arguments accordingly.

This is not to claim that no scholar is reassessing the literature on how states fight against insurgents and their supporters in the civilian population. In fact, scholars are exploring and refining some important arguments, especially the regime type thesis. ${ }^{97}$ This article supports this type of endeavour by showing that historical research on Britain's decolonisation conflicts strengthens the case for a reappraisal of the main explanations for indiscriminate violence in counterinsurgency. ${ }^{98}$

The case for political scientists to reassess their theses may not simply hinge upon the historiography of Britain's decolonisation conflicts. Historical studies on the decolonisation wars of other states include data on relatively overlooked 
conflicts, like the French campaign in Madagascar (1947-1949), the Dutch campaign in the East Indies (1945-1949), or the Portuguese campaigns in Africa (1961-1974).${ }^{99}$ Future research may explore the extent to which those studies confirm or further challenge political science explanations for civilian targeting.

Interestingly, historical research on colonial wars may also point social scientists towards fruitful directions to revise their arguments. Political scientists have tried to explain civilian victimisation as the result of very few dominant independent variables that would overwhelm any other potential causal factor. That approach led to theses that may have oversimplified a complex phenomenon like indiscriminate violence and failed in easy tests. The dubious performance of political science theses would vindicate historians' understanding of social and political phenomena as the product of different factors that converge simultaneously and interact with one another. ${ }^{100}$ Historical studies on imperial warfare - including expeditionary counterinsurgency - acknowledge that the image of the enemy, military doctrines, military culture, military technology, and insurgents' skills in guerrilla warfare played an important role in shaping the level of brutality, along with other factors. ${ }^{101}$ Yet, those studies conclude that 'no one factor was alone sufficient' and 'none was indispensable' to explain the extent of indiscriminate violence: the brutality of colonial wars depended on combinations of intersecting and mutually reinforcing causes that would be difficult to disaggregate without losing explanatory power. ${ }^{102}$

Future attempts to revise social scientific theses of civilian victimisation may build upon this insight. Instead of trying to isolate few independent variables that would be powerful enough to account for brutality against non-combatants, political scientists may develop more convincing theories by looking for groups of converging causal factors behind the incidence of civilian victimisation in counterinsurgency.

\section{Notes}

1. Thompson, Defeating Communist Insurgency.

2. Nagl, Counterinsurgency Lessons from Malaya and Vietnam, 205; Charters, "The British Adaptation to Low Intensity Conflicts," 194, 228; Mockaitis, "The Origins of British Counterinsurgency," 213, 215; Mockaitis, British Counterinsurgency 1919-1960, 57; Mockaitis, "Low-Intensity Conflict," 1012; Thornton, "The British Army and the Origins of its Minimum Force Philosophy". See also McInnes, Hot War Cold War, 116-7; Ucko, 
"Countering Insurgents Through Distributed Operations," 51-63; Mahnken, "The British Approach to Counterinsurgency," 227-32 .

3. Some of the most significant revisionist works are Newsinger, "Minimum Force, British Counterinsurgency"; Newsinger, British Counterinsurgency; French, The British Way in Counterinsurgency; Grob-Fitzgibbon, Imperial Endgame; Anderson, Histories of the Hanged; Elkins, Britain's Gulag; Bennett, Fighting the Mau Mau; French, Fighting EOKA. See also Reis, "The Myth of British Minimum Force"; Dixon, "'Hearts and Minds'?"; Hack, "The Malayan Emergency as Counterinsurgency Paradigm"; Hack, "Everyone Lived in Fear"; Bennett, "A Very Salutary Effect"”; Anderson, "British Abuse and Torture".

4. Reis, "The Myth of British Minimum Force," 275.

5. French, The British Way in Counterinsurgency, chapter 4.

6. Hack, "Everyone Lived in Fear".

7. These phases have been described as counter-terror (1948-949), clear and hold (1950-1952), and optimisation (1952-1960). See Ibid., 673.

8. Since this article tests political science arguments about civilian victimisation in counterinsurgency, it is necessary to consider the main definitions provided by political scientists themselves. According to Alexander Downes civilian victimisation would be a 'government-sanctioned military strategy that intentionally targets and kills non-combatants or involves operations that will predictably kill large numbers of non-combatants'. See Downes, Targeting Civilians, 14. Downes' definition, however, would miss acts of violence that may not be intended to kill but would still harm civilians, like rape. Ivan Arreguìn-Toft offers a more comprehensive definition of civilian victimisation as 'the deliberate or systematic harm on non-combatants (e.g. rape, murder, torture) in pursuit of a military or political objective'. See Arreguìn-Toft, How the Weak Win Wars, 31. This definition is consistent with recent studies on civilian suffering in warfare, according to which violence against non-combatants includes murder, torture, rape, dispossession, deportation and displacement, disease and famine. See Slim, Killing Civilians, chapters 2 and 3. Accepting such a comprehensive understanding of the concept, this article will use the terms civilian victimisation, civilian targeting, and indiscriminate violence as synonyms.

9. These campaigns were the major sources of evidence in the historical debate on the characteristics of British counterinsurgency during decolonisation.

10. See Elman and Fendius Elman, eds. Bridges and Boundaries.

11. On political scientists' reluctance to update their theories in response to new historical evidence, see Wohlforth, "A Certain Idea of Science". See also Lieber, "The New History of World War I".

12. Engelhardt, "Democracies, Dictatorships, and Counterinsurgency," 57. See also Downes, Targeting Civilians in War, 212-3; Valentino, Final Solutions, 229-30; DeVore, "Institutions, Organisational Culture, and Counterinsurgency Operations," 171-2; Nagl, Counterinsurgency Lessons from Malaya and Vietnam; Long, The Soul of Armies, chapter 8.

13. George and Bennett, Case Studies and Theory Development, 21-2.

14. Ibid. 181; Van Evera, Guide to Methods, 56.

15. See Beckett, Modern Insurgency and Counterinsurgency. 
16. Since the historical scholarship on British decolonisation mostly addressed expeditionary counterinsurgency, this article will do the same. Interestingly, most of the detailed case studies elucidating the causal logic of political science theses of indiscriminate violence in anti-guerrilla warfare focus on expeditionary counterinsurgency. See notes 17 and 19.

17. Mack, "Why Big Nations Lose Small Wars"; Arreguin-Toft, How the Weak Win Wars; Merom, How Democracies Lose Small Wars; Engelhardt, "Democracies, Dictatorships, and Counterinsurgency"; Caverley, "The Myth of Military Myopia"; Caverley, "Explaining U.S. Military Strategy in Vietnam"; Downes, "Draining the Sea by Filling the Graves"; Lyall and Wilson III, "Rage against the Machines"; Byman, "Death Solves All Problems""; Hazelton, "The 'Hearts and Minds' Fallacy".

18. See especially the works by Merom, Caverley, and Lyall and Wilson III in note 17.

19. Valentino et al., "Draining the Sea"”; Valentino, Final Solutions, chapter 6; Downes, Targeting Civilians in War, chapter 5; Kahl, "In the Crossfire or the Crosshairs?"; DeVore, "Institutions, Organisational Culture, and Counterinsurgency Operations"; Long, The Soul of Armies.

20. Merom, How Democracies Lose Small Wars, 15, 18-21, 24. On democracy as a source of self-restraint see also Engelhardt, "Democracies, Dictatorships, and Counterinsurgency".

21. Caverley, "The Myth of Military Myopia," 120, 127-39.

22. Ibid., 140-55.

23. DeVore, "Institutions, Organisational Culture, and Counterinsurgency Operations".

24. Posen, The Sources of Military Doctrine, 41-59.

25. DeVore, "Institutions, Organisational Culture, and Counterinsurgency Operations," 174.

26. Ibid., 175.

27. Kier, "Culture and Military Doctrine," 69-70; Kahl, "In the Crossfire or the Crosshairs?" 37-8; Long, The Soul of Armies, chapter 2.

28. For a historical study that shows how military culture shapes the use of indiscriminate violence in counterinsurgency see Hull, Absolute Destruction.

29. Lyall and Wilson III, "Rage against the Machines," 72.

30. Ibid., 75-7.

31. Ibid.

32. Valentino et al., "Covenants without the Sword," 349-50.

33. Salter, Barbarians and Civilisation in International Relations, 38-9.

34. Slim, Killing Civilians, 122.

35. Ibid., 204-9

36. Downes, Targeting Civilians in War, 31-2.

37. Valentino et al. , "Draining the Sea'," 385-6

38. Ibid., 386-7. As Hugo Slim points out, the decision to use indiscriminate violence for strategic reasons does not deny the existence of civilians, but suspends the principle of non-combatant immunity temporarily for the sake of military necessity. Slim, Killing Civilians, 122-3, 151-61.

39. Ibid.; Downes, Targeting Civilians in War, 165-77, 212-3, 237-8.

40. Alexander Downes, for instance, used large samples and statistical methods to test desperation to win against regime type, military organisational factors, 
and the image of the enemy as causes of civilian targeting in warfare; however, his data set only includes interstate conventional wars. In spite of that, Downes does contend that desperation to win would explain civilian targeting in anti-guerrilla warfare too, but he only tests his candidate causal factor on a single case of counterinsurgency: the Second-Anglo Boer War (1900-1902). See Downes, Targeting Civilians in War, chapters 2 and 5.

41. See Valentino et al., "Draining the Sea"'. Valentino et al. only considered cases in which the counterinsurgent intentionally killed at least 50,000 civilians in five years. One may presume that factors that can account for mass killing and genocide can also explain cases in which violence against non-combatants resulted in a lower number of civilian deaths. This article suggests that, in fact, this is not necessarily the case.

42. See Merom, How Democracies Lose Small Wars; Caverley, "The Myth of Military Myopia"; Long, The Soul of Armies; Kahl, "In the Crossfire or the Crosshairs?"

43. Engelhardt, "Democracies, Dictatorships, and Counterinsurgency," 57. See also Downes, Targeting Civilians in War, 212-3; Valentino, Final Solutions, 229-30; DeVore, "Institutions, Organisational Culture, and Counterinsurgency Operations," 171-2.

44. Anderson, Histories of the Hanged, 311-27; Bennett, Fighting the Mau Mau, 223-4.

45. Elkins, Britain's Gulag, chapter 3; Newsinger, British Counterinsurgency, 77-80; Anderson, "British Abuse and Torture".

46. Bennett, Fighting the Mau Mau, 165-70.

47. Blacker, "The Demography of Mau Mau," 225-6.

48. French, The British Way in Counterinsurgency, 222-6.

49. Bennett, Fighting the Mau Mau, 48-50.

50. Anderson, Histories of the Hanged, 326; Elkins, Britain's Gulag, 291-8, 33240.

51. Hack, "Everyone Lived in Fear".

52. Bennett, "“A Very Salutary Effect"”.

53. Ibid., 419.

54. Hack, "Everyone Lived in Fear," 673.

55. Ibid.

56. Newsinger, British Counterinsurgency, 32.

57. Bennett, Fighting the Mau Mau, 43-4.

58. Ibid., chapter 3; Reis, "The Myth of British Minimum Force".

59. French, The British Way in Counterinsurgency, 16-27, 33-41.

60. Ibid., 167-73. See also French, Fighting EOKA, 205-6, 214; Bennett, Fighting the Mau Mau, 194.

61. See Bennett, "A Very Salutary Effect"”; Bennett, Fighting the Mau Mau, 29. Revisionist historians, however, never contend that factors like the military culture of the British Army or lack of information were sufficient to explain British violence against civilians during decolonisation. They simply suggest that these factors are necessary, but in a multi-causal explanation including other contributing factors.

62. DeVore, "Institutions, Organisational Culture and Counterinsurgency Operations," 174.

63. French, The British Way in Counterinsurgency, 76-82, 86-96. 
64. Elkins, Britain's Gulag; Anderson, "Surrogates of the State"; Branch, "Enemy Within"; Branch, Defeating Mau Mau.

65. Bennett, Fighting the Mau Mau, 172-3.

66. Ibid., 173-5.

67. Branch, Defeating Mau Mau, 71; Anderson, "Surrogates of the State".

68. Anderson, Histories of the Hanged, 130-2.

69. Anderson, "Surrogates of the State," 164-5.

70. Bennett, Fighting the Mau Mau, chapter 8; Grob-Fitzgibbon, Imperial Endgame, 274-5.

71. Elkins, Britain's Gulag, 319-32; Anderson, "British Abuse and Torture".

72. Anderson, Histories of the Hanged, 315-7; Blacker, "The Demography or Mau Mau," 225-6.

73. Recent political science works on military culture in counterinsurgency acknowledge that the British Army was not the only organisation involved in the repression of the Mau Mau insurgency in Kenya. Yet, those studies still miss that political leaders and civil agencies played the main role in shaping the fate of civilians. See, Long, The Soul of Armies, chapter 8.

74. Charters, The British Army and Jewish Insurgency, 88-9; TNA, "Cyprus Emergency: Army Reinforcements, 1955-1958”, WO 32/16260.

75. The Jewish community in Palestine and the Greek Cypriot population numbered 560,000 and 521,000 respectively. See Newsinger, British Counterinsurgency, 12; French, Fighting EOKA, 14.

76. Newsinger, British Counterinsurgency, 16-7, 96.

77. Ibid., 14; French, Fighting EOKA, 57-8, 73-4.

78. Anderson, "Policing and Communal Conflict," 184-5.

79. Grob-Fitzgibbon, Imperial Endgame, 328-9, 335-6; Newsinger, British Counterinsurgency, 15-28.

80. French, Fighting EOKA, 194-202, 221-6, 233-6. Prisoners and captured documents were Britain's main source of intelligence during the Cyprus campaign.

81. French, The British Way in Counterinsurgency, 67.

82. Holland, Britain and the Revolt in Cyprus, 268.

83. Ibid., 288.

84. Ibid., 187.

85. French, Fighting EOKA, 177.

86. Anderson, Histories of the Hanged, 4.

87. Grob-Fitzgibbon, Imperial Endgame, 249.

88. Ibid., 256.

89. See Bennett, Fighting the Mau Mau, 12-9, 160-80.

90. Downes, Targeting Civilians in War, 212-3.

91. Hack, "Everyone Lived in Fear"; Hack, "The Malayan Emergency as Counterinsurgency Paradigm".

92. Bennett, "“A Very Salutary Effect"”.

93. Quoted in Ibid., 428.

94. Ibid., 424.

95. Guzzini, "The Significance and Roles of Teaching Theory," 99.

96. Waltz, Theory of International Politics, 8-10.

97. Ucko, "The People Are Revolting"”. 
98. The historiography of Britain's decolonisation conflicts would be less helpful as a source of data to test explanations for insurgent violence against civilians. Indeed, since revisionist historians focus on Britain's performance in antiguerrilla warfare, they mostly provide evidence about counterinsurgent violence. For a recent explanation for insurgent violence, see Boyle, "Bargaining, Fear, and Denial". According to Boyle, insurgent violence would be a way of bargaining within and between sectarian communities competing for power. Insurgents' attacks against civilians would signal capacity and willingness to fight to rival sects. Killing civilians would also help the perpetrator to maintain political momentum and attract more recruits than other armed groups in rival communities. At the same time, the show of power deriving from civilian targeting would enable armed groups to establish themselves in intra-sectarian political contests. The ensuing climate of fear would induce civilians to support those groups that can offer protection, which would encourage the proliferation of militias and cause further violence.

99. See Clayton, The Wars of French Decolonisation; Luttikhuis and Moses, eds. Colonial Counterinsurgency and Mass Violence; Cann, Counterinsurgency in Africa.

100. Elman and Fendius Elman, "Negotiating International History", 23.

101. Walter, Colonial Violence, chapter 3.

102. Ibid., 190-1.

\section{Bibliography}

Anderson, David M. "Policing and Communal Conflict: The Cyprus Emergency 1954-1960." In Emergency and Disorder in the European Empires after 1945, edited by Robert Holland, 177-206. London: Frank Cass, 1994.

Anderson, David M. Histories of the Hanged: Britain's Dirty War in Kenya and the End of Empire. London: Weidenfeld \& Nicolson, 2005.

Anderson David M. "Surrogates of the State: Collaboration and Atrocity in Kenya's Mau Mau War." In The Barbarisation of War, edited by George Kassimeris, 159174. London: Hurst, 2006.

Anderson, David M. "British Abuse and Torture in Kenya's Counterinsurgency, 1952-1960." Small Wars and Insurgencies 23, no. 4-5 (2012): 700-719.

Arreguìn-Toft, Ivan. How The Weak Win Wars. A Theory of Asymmetric Conflict. Cambridge: Cambridge University Press, 2005.

Beckett, Ian F. W. Modern Insurgencies and Counterinsurgencies. Guerrillas and their Opponents since 1750. London: Routledge, 2001.

Bennett, Huw. "“A Very Salutary Effect': The Counter-Terror Strategy in the Early Malayan Emergency, June 1948-December 1949.” Journal of Strategic Studies 32, no. 3 (2009): 415-444.

Bennett, Huw. Fighting the Mau Mau: The British Army and Counter-Insurgency in the Kenya Emergency. Cambridge: Cambridge University Press, 2013.

Blacker, John. "The Demography of Mau Mau: Fertility and Mortality in Kenya in the 1950s: A Demographer Viewpoint." African Affairs 106, no. 423 (2007): 205227. 
Boyle, Michael J. "Bargaining, Fear, and Denial: Explaining Violence against Civilians in Iraq, 2004-2007", Terrorism and Political Violence 21, no. 2 (2009): 261-287.

Branch, Daniel. "Enemy Within: Loyalists and the War against Mau Mau in Kenya." Journal of African History 48, no. 2 (2007): 291-315.

Branch, Daniel. Defeating Mau Mau, Creating Kenya: Counterinsurgency, Civil War, Decolonisation. Cambridge: Cambridge University Press, 2009.

Byman, Daniel. "'Death Solves All Problems': The Authoritarian Model in Counterinsurgency." Journal of Strategic Studies 39, no. 1 (2016): 62-93.

Cann, John P. Counterinsurgency in Africa: The Portuguese Way of War, 19611974. Westport, CT: Praeger, 1997.

Caverley, Jonathan D. "The Myth of Military Myopia: Democracy, Small Wars, and Vietnam." International Security 34, no. 3 (2009/10): 119-157.

Caverley, Jonathan D. "Explaining US Military Strategy in Vietnam: Thinking Clearly about Causation." International Security 35, no. 3 (2010/11): 124-143.

Charters, David A. "The British Adaptation to Low Intensity Conflicts from Palestine to Northern Ireland." In Armies in Low Intensity Conflicts, edited by David Charters, 169-249. London: Brassey's, 1989.

Charters, David A. The British Army and Jewish Insurgency in Palestine, 19451947. Basingstoke: Palgrave Macmillan, 1989.

Clayton, Anthony. The Wars of French Decolonisation. London: Longman, 1994.

DeVore, Marc R. "Institutions, Organisational Culture, and Counterinsurgency Operations: Why Do States Fight Similar Campaigns Differently?" Comparative Strategy 32, no. 3 (2013): 169-191.

Dixon, Paul. "'Hearts and Minds'? British Counter-Insurgency from Malaya to Iraq." Journal of Strategic Studies 32, no. 3 (2009): 353-381.

Downes, Alexander B. "Draining the Sea by Filling the Graves: Investigating the Effectiveness of Indiscriminate Violence as a Counterinsurgency Strategy." Civil Wars 9, no. 4 (2007): 420-444.

Downes, Alexander B. Targeting Civilians in War. Ithaca, NY \& London: Cornell University Press, 2008.

Elkins, Caroline. Britain's Gulag: The Brutal End of Empire in Kenya. London: Jonathan Cape, 2005.

Elman, Colin and Miriam Fendius Elman, eds. Bridges and Boundaries. Historians, Political Scientists and the Study of International Relations. Cambridge, MA: The MIT Press, 2001.

Elman, Colin and Miriam Fendius Elman, "Negotiating International History and Politics". In Bridges and Boundaries. Historians, Political Scientists and the Study of International Relations, edited by Colin Elman and Miriam Fendius Elman, 1-36, Cambridge, MA: The MIT Press, 2001.

Engelhardt, Michael J. "Democracies, Dictatorships, and Counterinsurgency: Does Regime Type Really Matter?” Conflict Quarterly 12, no. 3 (1992): 52-63.

French, David. The British Way in Counterinsurgency, 1945-1967. Oxford: Oxford University Press, 2011.

French, David. Fighting EOKA. The British Counterinsurgency Campaign on 
Cyprus, 1955-1959. Oxford: Oxford University Press, 2015.

George, Alexander L. and Andrew Bennett. Case Study and Theory Development in the Social Sciences. Cambridge, MA: The MIT Press, 2004.

Grob-Fitzgibbon, Benjamin. Imperial Endgame. Britain's Dirty Wars and the End of Empire. Basingstoke: Palgrave Macmillan, 2013.

Guzzini, Stefano. "The Significance and Roles of Teaching Theory in International Relations." Journal of International Relations and Development 4, no. 2 (2001): 98-117.

Hack, Karl. "The Malayan Emergency as Counterinsurgency Paradigm.” Journal of Strategic Studies 32, no. 3 (2009): 383-414.

Hazelton, Jacqueline L. “"The Hearts and Minds Fallacy': Violence, Coercion, and Success in Counterinsurgency Warfare.” International Security 42, no. 1 (2017): 80-113.

Holland, Robert. Britain and the Revolt in Cyprus, 1954-1959. Oxford: Clarendon Press, 1998.

Hull, Isabel V. Absolute Destruction. Military Culture and the Practices of War in Imperial Germany. Ithaca, NY \& London: Cornell University Press, 2004.

Kahl, Colin H. "In the Crossfire or the Crosshairs? Norms, Civilian Casualties, and US Conduct in Iraq." International Security 32, no. 1 (2007): 7-46.

Kier, Elizabeth. "Culture and Military Doctrine. France between the Wars." International Security 19, no. 4 (1995): 65-93.

Lieber, Keir A. "The New History of World War I and What It Means for International Relations Theory." International Security 32, no. 2 (2007): 155191.

Long, Austin. The Soul of Armies. Counterinsurgency Doctrine and Military Culture in the US and the UK. Ithaca, NY \& London: Cornell University Press, 2016.

Luttikhuis, Bart and A. Dirk Moses, eds. Colonial Counterinsurgency and Mass Violence. The Dutch Empire in Indonesia. London: Routledge, 2014.

Lyall, Jason and Isaiah Wilson III. "Rage against the Machines: Explaining Outcomes in Counterinsurgency Wars." International Organisation 63, no. 1 (2009): 67-106.

Mack, Andrew. "Why Big Nations Lose Small Wars: the Politics of Asymmetric Conflict." World Politics 27, no. 2 (1975): 175-200.

Mahnken, Thomas. "The British Approach to Counterinsurgency: An American View." Defense and Security Analysis 23, no. 2 (2007): 227-232.

McInnes, Colin. Hot War, Cold War: The British Army's Way in Warfare, 1945-95. London: Brassey's, 1996.

Merom, Gil. How Democracies Lose Small Wars. State, Society, and the Failures of France in Algeria, Israel in Lebanon, and the United States in Vietnam. Cambridge: Cambridge University Press, 2003.

Mockaitis, Thomas. "The Origins of British Counterinsurgency." Small Wars and Insurgencies 1, no. 3 (1990): 209-225.

Mockaitis, Thomas. British Counterinsurgency, 1919-1960. Basingstoke: Macmillan, 1990. 
Mockaitis, Thomas. "Low-Intensity Conflict: The British Experience." Conflict Quarterly 13, no. 1 (1993): 7-16.

Nagl, John. Counterinsurgency Lessons from Malaya and Vietnam. Learning to Eat Soup with a Knife. Westport, CT: Praeger, 2002.

Newsinger, John. "Minimum Force, British Counterinsurgency, and the Mau Mau Rebellion." Small Wars and Insurgencies 3, no. 1 (1992): 47-57.

Newsinger, John. British Counterinsurgency. From Palestine to Northern Ireland. Basingstoke: Palgrave, 2002.

Posen, Barry. The Sources of Military Doctrine. France, Britain and Germany between the World Wars. Ithaca, NY \& London: Cornell University Press, 1984.

Reis, Bruno C. "The Myth of British Minimum Force in Counterinsurgency Campaigns during Decolonisation, (1945-1970)." Journal of Strategic Studies 34, no. 2 (2011): 245-279.

Salter, Mark B. Barbarians and Civilisation in International Relations. London: Pluto, 2002.

Slim, Hugo. Killing Civilians. Methods, Madness, and Morality in War. London: Hurst, 2007.

Thompson, Robert. Defeating Communist Insurgency: Experiences from Malaya and Vietnam. New York: Praeger, 1966.

Thornton, Rod. "The British Army and the Origins of its Minimum Force Philosophy." Small Wars and Insurgencies 15, no. 1 (2004): 83-106.

Ucko, David H. "Countering Insurgents through Distributed Operations: Insights from Malaya 1948-1960." Journal of Strategic Studies 30, no. 1 (2007): 47-72.

Ucko, David H. “"The People Are Revolting': An Anatomy of Authoritarian Counterinsurgency." Journal of Strategic Studies 39, no. 1 (2016): 29-61.

Valentino, Benjamin. Final Solutions: Mass Killing and Genocide in the Twentieth Century. Ithaca, NY \& London: Cornell University Press, 2004.

Valentino, Benjamin, Paul Huth, and Dylan Balch-Lindsay, "'Draining the Sea': Mass Killing and Guerrilla Warfare.” International Organisation 58, no. 2 (2004): 375-407.

Valentino, Benjamin, Paul Huth, and Sarah Croco. "Covenants without the Sword: International Law and the Protection of Civilians in Times of War." World Politics 58, no. 3 (2006): 339-377.

Van Evera, Stephen. Guide to Methods for Students of Political Science. Ithaca, NY \& London: Cornell University Press, 1997.

Walter, Dierk. Colonial Violence. European Empires and the Use of Force. London: Hurst, 2017.

Waltz, Kenneth N. Theory of International Politics. Reading, MA: Addison-Wesley, 1979.

Wohlforth, William C. "A Certain Idea of Science: How International Relations Theory Avoids the New Cold War History." Journal of Cold War Studies 1, no. 2 (1999): 39-60. 